\title{
Effects of soil cultivation and environmental changes on maize yield
}

\author{
Gergő Sedlák - Adrienn Széles \\ University of Debrecen Faculty of Agricultural and Food Sciences and Environmental Management, \\ Institute for Land Utilisation, Technology and Regional Development, Debrecen \\ szelesa@agr.unideb.hu
}

\section{SUMMARY}

We evaluated the relationships among soil cultivation and other agrotechnical factors (fertilization, number of plants and hybrid) within the framework of a multifactorial long-term experiment set at the Látókép Experimental Site of the Centre for Agricultural Sciences of the University of Debrecen in mid-heavy chalcareous chernozem soil based on a long-term experiment conducted for a 5-year period (20022006).

Based on the evaluation of soil cultivation by the average of treatments, it may be assessed that spring ploughing $\left(8.204 t\right.$ ha $\left.{ }^{-1}\right)$ provides more favourable conditions to the stand compared to spring shallow cultivation; however, this did not result in a significant difference. Spring ploughing considerably increased the yield of hybrid FAO 300 in dry years, whereas it considerably increased the yield of hybrid FAO 400 in favourable crop years. A stand of 70 thousand stems/ha provided the higher yield result in both soil cultivation types. It was sufficient to use a fertilizer dose of $120 \mathrm{~kg} \mathrm{~N} \mathrm{ha-1} \mathrm{for} \mathrm{economical} \mathrm{production.}$

Keywords: spring ploughing, shallow cultivation, maize

\section{ÖSSZEFOGLALÁS}

Debreceni Egyetem Agrártudományi Központ Látóképi Kisérleti Telepén középkötött mészlepedékes csernozjom talajon beállitott multifaktoriális tartamkisérletben végeztük el a talajmüvelés és a többi agrotechnikai tényezö (mütrágyázás, növényszám és hibrid) összefüggéseinek értékelését 5 éves időszakot átfogó (2002-2006) vizsgálat alapján.

A talajmüvelés hatását értékelve - a kezelések átlagában - megállapitható, hogy a tavaszi szántás (8,204 t/ha) kedvezöbb feltételeket biztositott a növényállomány számára, mint a tavaszi sekélymüvelés, azonban ez szignifikáns különbséget nem eredményezett. A tavaszi szántás száraz években a FAO 300-as, kedvezö évjáratban a FAO 400 hibrid termését növelte jelentös mértékben. A 70 ezres tö/ha-os növényállomány biztositotta mindként talajmüvelési változatban a nagyobb terméseredményt. A gazdaságos termeléshez elegendö volt a $120 \mathrm{~kg} N / \mathrm{ha}$ mütrágyaadag kijuttatása.

Kulcsszavak: tavaszi szántás, sekélymüvelés, kukorica

\section{INTRODUCTION}

Regarding autumn ploughing, Hungarian special literature sources consider the $22-25 \mathrm{~cm}$ depth optimal (Sipos, 1972; Kováts, 1974; Győrffy, 1976; Kismányoky and Balázs, 1996; Nagy, 1996; Nagy et al., 2006). A ploughing deeper than the optimal one mainly increases costs, it does not result in extra yield, and it increases the risk of uncertainty as well. Sipos and Hegedüs (1982) think that in hard and medium-hard soils, following rotary cultivation carried out in a $15 \mathrm{~cm}$ depth before autumn ploughing and sowing in a $30 \mathrm{~cm}$ depth, a spring disking in a $15 \mathrm{~cm}$ depth may be regarded optimal, however, in such cases a $20-22 \mathrm{~cm}$ spring ploughing is not favourable.

Bánházi and Fülöp (1975) proved that contrary to ploughing, in the cases of certain tools without rotation even 6-14 mm humidity may be saved in dry weather, however, this may only be achieved if work operations are carried out with the most favourable humidity content and at the most favourable time.

In a dry crop year the water content of soil significantly reduces in the case of spring ploughing as well therefore Surányi (1957) and Nagy (2012) recommended that it should be eliminated, however, in an ideal crop year spring ploughing may also be considered as basic cultivation. Hegedüs (1984) says that autumn ploughing proved to be the best among the different methods of cultivation, the rotary cultivator and the disc resulted in $10 \%$ less yield, whereas spring ploughing resulted in $14 \%$ less yield, contrary to this Káposzta (1968) did not experience a considerable difference between the effects of autumn and spring ploughing exercised on the yield.

Compared to shallow cultivation without spring ploughing, autumn ploughing provides extra yield in the clayey soil with deep tilth, which was proved by Nagy (1995). The extra yield by hectares was by approximately $9 \%$ higher in the case of autumn ploughing than in basic cultivation without ploughing. The advantages of autumn ploughing are reduced in the droughty years. They reach maximum half a ton. Although basic cultivation carried out in spring without shallow ploughing is more favourable, it may be needed in certain years (Birkás et al., 1999). Fenyves (1997) states that the conditions of ploughing and loosening proved to be the more favourable to maize.

To the effect of soil cultivation in the last decades our soils became more packed so our water management considerably reduced (Birkás, 1987). The reason for this is the use of heavy machines and the increased number of courses (Stefanovits, 1975; Bird, 1982; Boels, 1982; Dickson, 1983; Rátonyi, 1999; Rátonyi et al., 2007). Due to this reason, cultivation methods and tools to protect soil started to be implemented (Barta and Jóri, 1979; Sörös and Soós, 1994; Rátonyi et al., 2005). However, the effects of these cultivation methods cannot 
be only restricted to the changes of soil structure, but thermal and humidity conditions, as well as the dynamics of nutrient mobilization exercising a positive effect on the quantity of yield shall be also taken into consideration (Gyuricza et al., 2012). The effect of soil cultivation exercised on yield result and soil should be only evaluated in a soil cultivation system maintained for several years (Győrffy, 1977; Nyiri, 1988; Rátonyi et al., 2005; Nagy, 2012; Ványi and Nagy, 2012; Ványiné et al., 2012).

The aim of the thesis is to evaluate the relationships between soil cultivation and crop year in a multifactorial long-term experiment, based on the comprehensive study conducted for 5 years (2002-2006).

\section{MATERIAL AND METHODS}

We carried out the tests at the Látókép Experimental Site of the Centre for Agricultural Sciences of the University of Debrecen on mid-heavy chalcareous chernozem.

This thesis evaluates the effects exercised on yields by two types of soil cultivation (22 $\mathrm{cm}$ deep spring ploughing and $12 \mathrm{~cm}$ deep spring shallow cultivation), and by three fertilization treatments (without fertilization, $120 \mathrm{~kg} \mathrm{~N}+90 \mathrm{~kg} \mathrm{P}_{2} \mathrm{O}_{5}+106 \mathrm{~kg} \mathrm{~K}_{2} \mathrm{O} \mathrm{ha}^{-1}, 240 \mathrm{~kg} \mathrm{~N}+180 \mathrm{~kg}$ $\mathrm{P}_{2} \mathrm{O}_{5}+212 \mathrm{~kg} \mathrm{~K}_{2} \mathrm{O} \mathrm{ha}^{-1}$ ), in the cases of three hybrids (FAO 200, FAO 300, FAO 400), two plant numbers (50 and 70 thousand/ha), and treatments with and without irrigation. In the main version with irrigation the quantity of irrigation water was $100 \mathrm{~mm}$ in 2002, $85 \mathrm{~mm}$ in 2003, $75 \mathrm{~mm}$ in 2004, $30 \mathrm{~mm}$ in 2005, and $50 \mathrm{~mm}$ in 2006. The harvested grain crop was given with a humidity content of $14 \%$.
Soil: The average $\mathrm{pH}_{\mathrm{KCl}}$ value of the soil is 6.6 , the Arany-type compactness number is 39 in the upper $20 \mathrm{~cm}$ layer. The total quantity of water-soluble salts is $0.04 \%$. Carbonated lime content in the upper $80 \mathrm{~cm}$ of the soil is around $0 \%$ (lime deficient), but it is $12 \%$ from $100 \mathrm{~cm}$ (medium limy). Organic material content is $2.3 \%$ in the upper $20 \mathrm{~cm}$ layer of the soil, and it does not exceed $1.00 \%$ at a depth of $120 \mathrm{~cm}$. Potassium supply of the soil is good, its P-supply is average.

Weather: Weather was evaluated based on the data measured by the automated weather station located in the area of the experiment. Based on the quantity of precipitation that fell in the growing season, the effective heat sum, and the potential evapotranspiration values, homogeneous groups were formed by means of hierarchical cluster analysis. The years could be classified as follows: dry, droughty year: 2002, dry year: 2003, rainy years: 2005, favourable, average years: 2004 and 2006 (Figure 1).

Statistical evaluation: For the assessment of the effects exercised on the yield by the treatments a general linear model (GLM) was used. For the comparison of treatment mean values, $5 \%$ significant difference $\left(\mathrm{LSD}_{5 \%}\right)$ was determined, as well as homogeneous groups were formed by means of multiple mean values comparison test, with the Duncan method. The yields within the homogeneous group do not differ from one another in the case of a significance level of 5\%. The evaluation was prepared with the use of the SPSS for Windows 13.0 statistical programme package.

Figure 1: Precipitation and effective heat units (HU) during the growing season (Debrecen, 2002-2006)

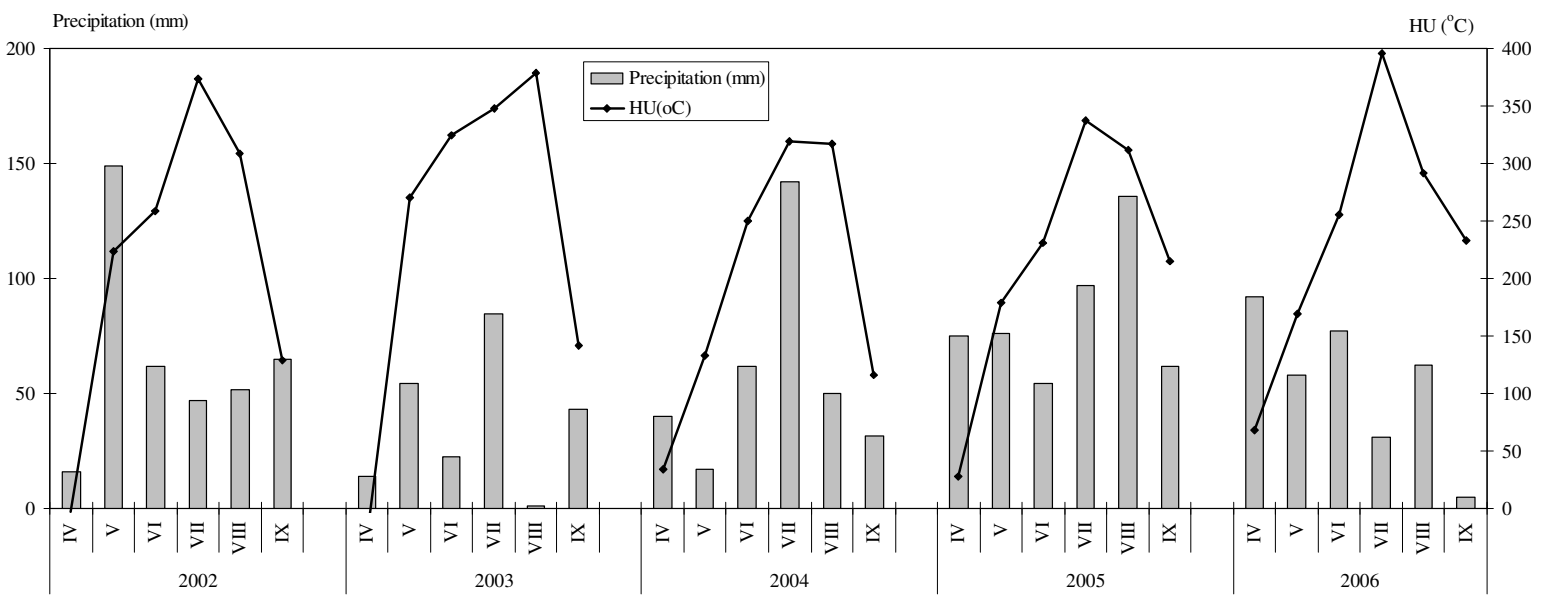

\section{RESULTS}

The two-patterned T-test results of the two soil cultivation types show that in the droughty year of 2002 spring ploughing - by the average of treatments - proved to be more successful by $1490 \mathrm{~kg} \mathrm{ha}^{-1}$ $(\mathrm{P}<0.001)$ compared to spring shallow cultivation. In the also dry year 2003 it was the area cultivated by means of spring shallow cultivation that gave greater yield, however, this difference of $706 \mathrm{~kg} \mathrm{ha}^{-1}$ cannot be significantly proved. The volumes of yields were the greatest in favourable crop years (2004), the difference between the two soil cultivation types was $606 \mathrm{~kg} \mathrm{ha}^{-1}$ $(\mathrm{P}<0.05)$. In the year of 2005 with extreme precipitation volume, and in the average crop year of 2006, the grain crops of the two soil cultivation types only slightly differed, which did not evidence significant difference (Table 1). 
The use of spring shallow cultivation in the case of FAO 400 hybrids was more favourable only in two years out of the examined 5 years, in 2002 by $856 \mathrm{~kg} \mathrm{ha}^{-1}$ $(\mathrm{P}<0.05)$ and in 2004 by $1051 \mathrm{~kg} \mathrm{ha}^{-1}(\mathrm{P}<0.05)$. In the other examined crop years there was no statistically provable deviation among the hybrids. The data show that it was only in 2002 that the productions of maize hybrids in the spring ploughing treatments did not show a significant difference. Spring ploughing increased the yield of FAO 300 hybrid to a considerable extent in dry years as in 2003 by $1091 \mathrm{~kg} \mathrm{ha}^{-1}(\mathrm{P}<0.05)$ and in 2006 by $1155 \mathrm{~kg} \mathrm{ha}^{-1}(\mathrm{P}<0.001)$, as well as in the year with lots of precipitation (2005), when yield increase was the greatest $\left(1870 \mathrm{~kg} \mathrm{ha}^{-1}, \mathrm{P}<0.001\right)$. In a favourable crop year (2004) the use of spring ploughing increased the yield result of the FAO 400 hybrid $(\mathrm{P}<0.05)$ to $997 \mathrm{~kg} \mathrm{ha}^{-1}$ (Table 2).

The effects of crop year and soil cultivation types on maize yield (Debrecen, 2002-2006)

\begin{tabular}{llllll}
\hline \multirow{2}{*}{\multicolumn{1}{c}{ Soil cultivation }} & \multicolumn{5}{c}{ Average yield $\left(\mathrm{t} \mathrm{ha}^{-1}\right)$} \\
\cline { 2 - 6 } & 2002 & 2003 & 2004 & 2005 & 2006 \\
\hline Spring ploughing & $5.376^{* * *}$ & $6.963^{\text {ns }}$ & $11.073^{*}$ & $9.553^{\text {ns }}$ & $8.057^{\text {ns }}$ \\
Spring shallow cultivation & 3.886 & 7.669 & 10.467 & 9.281 & 8.013 \\
\hline
\end{tabular}

Note: $* * * \mathrm{P}=0.001 \%, * \mathrm{P}=0.05, \mathrm{~ns}=$ non-significant

The effects of crop year and soil cultivation types on the yields of maize hybrids with different FAO numbers (Debrecen, 2002-2006)

\begin{tabular}{|c|c|c|c|c|c|c|c|}
\hline \multirow{3}{*}{ Soil cultivation } & \multirow{3}{*}{ Hybrid } & \multicolumn{5}{|c|}{ Yield $\left(\mathrm{t} \mathrm{ha}^{-1}\right)$} & \multirow{3}{*}{ Average } \\
\hline & & \multicolumn{5}{|c|}{ Years } & \\
\hline & & 2002 & 2003 & 2004 & 2005 & 2006 & \\
\hline \multirow[t]{2}{*}{ Spring shallow cultivation } & FAO 300 & $3.458^{* *}$ & $8.032^{\mathrm{ns}}$ & $9.942^{*}$ & $9.187^{\mathrm{ns}}$ & $8.224^{\mathrm{ns}}$ & 7.769 \\
\hline & FAO 400 & 4.314 & 7.306 & 10.993 & 9.375 & 7.801 & 7.958 \\
\hline Average & & 3.886 & 7.669 & 10.467 & 9.281 & 8.013 & 7.863 \\
\hline \multirow[t]{2}{*}{ Spring ploughing } & FAO 300 & $5.485^{\mathrm{ns}}$ & $7.508^{*}$ & $10.574^{*}$ & $10.488^{* * *}$ & $8.635^{* * *}$ & 8.538 \\
\hline & FAO 400 & 5.267 & 6.417 & 11.571 & 8.618 & 7.480 & 7.871 \\
\hline Average & & 5.376 & 6.963 & 11.073 & 9.553 & 8.057 & 8.204 \\
\hline
\end{tabular}

Note: $* * * \mathrm{P}=0.001 \%, * * \mathrm{P}=0.01, * \mathrm{P}=0.05, \mathrm{~ns}=$ non-significant

In the case of a stand of 70 thousand stems haspring shallow cultivation resulted in a greater yield in each examined year, however, it only had a statistically reliable yield growing effect in $2004\left(1336 \mathrm{~kg} \mathrm{ha}^{-1}\right.$, $\mathrm{P}<0.01)$ and in $2006\left(1034 \mathrm{~kg} \mathrm{ha}^{-1}, \mathrm{P}<0.01\right)$. In the case of spring ploughing it was also the stand of 70 thousand stems where greater yield occurred - except for the year of 2003 - however, significant yield increase occurred in $2002\left(668 \mathrm{~kg} \mathrm{ha}^{-1}, \mathrm{P}<0.05\right)$ and in $2004\left(1082 \mathrm{~kg} \mathrm{ha}^{-1}\right.$, $\mathrm{P}<0.05$ ) (Figure 2).

Figure 2: The effects of crop year and soil cultivation types on the yield with varying number of plants (Debrecen, 2002-2006)

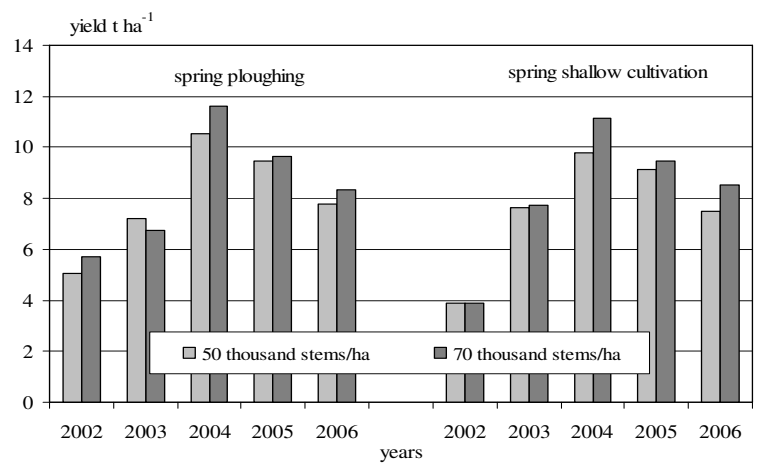

When examining the effects of fertilization it may be assessed that in both soil cultivation types and in all the examined 5 years there was a statistically also proved difference between yields of non-fertilized and fertilized lots. In the case of spring shallow cultivation, the average extra yield of fertilization was the greatest in the year 2005 with lots of precipitation (3.979 $\left.\mathrm{tha}^{-1}\right)$, whereas it was the smallest in the droughty year of $2002\left(2.154 \mathrm{tha}^{-1}\right)$. The fertilization treatment with $120 \mathrm{~kg}$ $\mathrm{N} \mathrm{ha}^{-1}$ resulted in an extra yield exceeding $3 \mathrm{t} \mathrm{ha}^{-1}$ in three years $(2003,2004$ and 2005) at a significance level of $0.1 \%$. The effect of spring ploughing on the extra yield of fertilization was the greatest in a favourable crop year $\left(3.516 \mathrm{tha}^{-1}\right)$, and this effect reduced to the greatest extent in the droughty year of 2002, when it was only $998 \mathrm{~kg} \mathrm{ha}^{-1}$. The fertilizer treatment with $120 \mathrm{~kg} \mathrm{~N} \mathrm{ha}^{-1}$ caused the greatest extra yield of $3.520 \mathrm{tha}^{-1}(\mathrm{P}<0.001)$ in a favourable crop year (Figure 3). 
Figure 3: The effects of crop year and soil cultivation types on the yield with varying fertilizer treatments (Debrecen, 2002-2006)

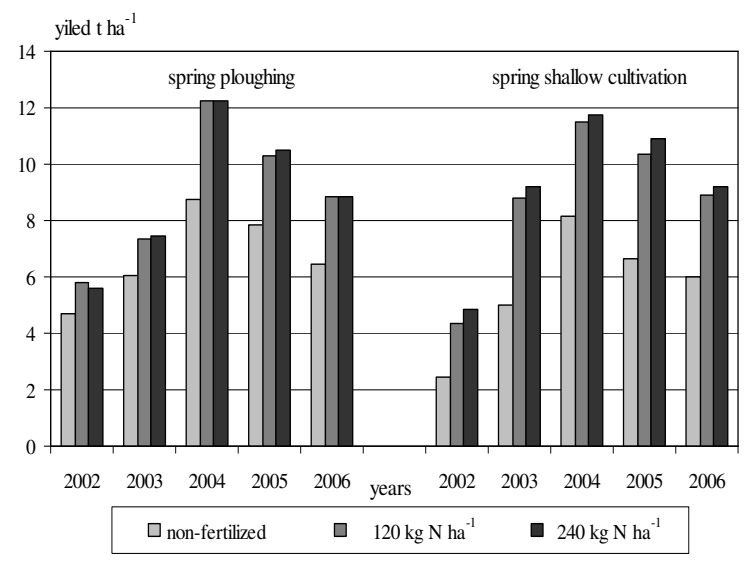

\section{CONCLUSIONS}

Based on the MQ value of the multifactorial variance analysis, in the examined years soil cultivation had the most significant yield modifying effect in 2002, this effect is proved at the level of $0.1 \%$, and in 2006 it did not show significant reliability. Out of the significant interactions, the soil cultivation $\times$ hybrid interaction proved to be more considerable in two years, in 2002 $(\mathrm{P}<0.01)$ and in $2005(\mathrm{P}<0.001)$.

In summary it may be assessed that - by the average of treatments - spring ploughing $\left(8.204 \mathrm{t} \mathrm{ha}^{-1}\right)$ provided the better condition for the maize, however, the extra yield of $341 \mathrm{~kg} \mathrm{ha}^{-1}$ did not prove to be a significant difference compared to the spring shallow cultivation $\left(7.863 \mathrm{tha}^{-1}\right)$.

\section{REFERENCES}

Bánházi J.-Fülöp G. (1975): A minimális talajművelés gépei. Mezőgazdasági Kiadó. Budapest.

Barta L.-Jóri J. (1979): Nehéz kultivátorok összehasonlító vizsgálata. Mg. Gépesítési Tanulmányok. Gödöllő. MÉM. MIM.

Bird, M. (1982): Effects of field traffic on yield under test. Farmers Weekly. 96. 23: 40

Birkás M. (1987): Szemléletváltozás a talajművelésben. Gazdálkodás. 28. 9: 47-52.

Birkás M.-Gyuricza Cs.-Gecse M.-Percze A. (1999): Ismételt tárcsás sekélymủvelés hatása egyes növénytermesztési tényezőkre barna erdőtalajon. Növénytermelés. 48. 4: 387-402.

Boels, D. (1982): Physical soil degradation in the Netherlands. Soil Degradation. Rotterdam. Balkema. 47-65.

Dickson, J. W. (1983): An assessment of seedbed compaction by open flatlugged, steel tractor wheels. I. Agric. Eng. Res. 28: 45-60.

Fenyves T. (1997): A talajművelés és a trágyázás hatás a talaj állapotára és a kukorica termésére gödöllői barna erdőtalajon. Növénytermelés. 46. 3: 289-298.

Győrffy B. (1976): A kukorica termésére ható növénytermesztési tényezők értékelése. Agrártudományi Közlemények. 35: 239-266.

Győrffy B. (1977): A földművelés rendszere és a kukoricatermesztés technológiájának alapelvei. A kukorica jelene és jövője. Budapest. 11-26.

Gyuricza, Cs.-Balla, I.-Tarnawa, Á.-Nyárai, H. F.-Kassai, K.Zsentpétery, Zs.-Jolánkai, M. (2012): Impact of precipitation on yield quantity and quality of wheat and maize crops. Időjárás. 116. 3: 211-220.

Hegedüs I. (1984): Tavaszi talajművelési módok vizsgálata kukorica monokultúrában. Növénytermelés. 33. 2: 171-177.

Káposzta J. (1968): Néhány fontosabb agrotechnikai tényező szerepe a kukoricatermesztés növelésében. Talajtermékenység. 3. 11: 41-59.

Kismányoky T.-Balázs J. (1996): Keszthelyi tartamkísérletek. PATE. Keszthely.

Kováts A. (1974): Talajművelési kísérletek kukorica monokultúrában. Talajtermékenység. 5: 1-9.

Nagy J.-Rátonyi T.-Megyes A. (2006): Mélylazítás a minőségi talajművelés jegyében. Agrofórum. 17. 9: 11-13.
Nagy J. (1995): A talajművelés, a mütrágyázás, a növényszám és az öntözés hatásának értékelése a kukorica (Zea mays L.) termésére. Növénytermelés. 44. 3: 251-260.

Nagy J. (1996): A mütrágyázás és a talajművelés kölcsönhatása a kukoricatermesztésben. Növénytermelés. 45. 3: 297-305.

Nagy J. (2012): Versenyképes kukoricatermesztés. Mezőgazda Kiadó. Budapest. 494

Nyiri L. (1988): A talajjavítás fejlesztésének lehetőségei. Akadémiai doktori értekezés. Karcag.

Rátonyi T. (1999): A talaj fizikai állapotának penetrométeres vizsgálata talajmüvelési tartamkísérletben. Disszertáció/PhD. 94.

Rátonyi T.-Megyes A.--Nagy J.-Sulyok D. (2005): A talaj-előkészítés minőségét befolyásoló talajjellemzők és a művelés utáni talajállapot összefüggései a kukoricatermesztésben. [In: Nagy J (szerk.) Kukorica hibridek adaptációs képessége és termésbiztonsága.] A kukoricakutatás és fejlesztés 30 éve. DE ATC Debrecen. 204-211.

Rátonyi T.-Megyes A.-Sulyok D. (2007): A talaj tömődöttségének penetrométeres vizsgálata. Acta Agronomica Óváriensis. 49. 2 445-449.

Sipos G. (1972): Földműveléstan. Mezőgazdasági Kiadó. Budapest.

Sipos S.-Hegedűs S. (1982): A kukoricatermelés, a talajművelés és a mütrágyázás közötti összefüggések. Növénytermelés. 31. 3: 245-254.

Sörös I.-Soós S. (1994): Szántás nélküli kukoricatermesztés. Mezőgazdasági Technika. 35. 3: 3-6.

Stefanovits P. (1975): Talajtan. Mezőgazdasági Kiadó. Budapest. 351

Surányi J. (1957): A kukorica és termesztése. Akadémiai Kiadó. Budapest.

Ványiné Széles, A.-Megyes, A.-Nagy, J. (2012): Irrigation and nitrogen effects on the leaf chlorophyll content and grain yield of maize in different crop years. Agricultural Water Management. 107: 133-144.

Ványiné Széles, A.-Nagy, J. (2012): Effect of nutrition and water supply on the yield and grain protein content of maize hybrids. Australian Journal of Crop Science. 6. 3: 381-290. 